\title{
Atypical morphological variants of congenital cataract in Down's syndrome
}

\author{
Sudarshan Khokhar, ${ }^{1}$ Mousumi Banerjee \\ Shweta Sandhu ${ }^{2}$
}

${ }^{1}$ Ophthalmology, All India Institute of Medical Sciences, New Delhi, India

${ }^{2} \mathrm{RPC}$, AllMS, All India Institute of Medical Sciences, New Delhi, India

\section{Correspondence to}

Dr Mousumi Banerjee; banerjeemou12@gmail.com

Accepted 2 May 2021
Check for updates

(c) BMJ Publishing Group Limited 2021. No commercial re-use. See rights and permissions. Published by BMJ.

\begin{tabular}{|l|}
\hline To cite: Khokhar S, \\
Banerjee M, Raj SJS, \\
et al. BMJ Case Rep \\
2021;14:e242759. \\
doi:10.1136/bcr-2021- \\
242759 \\
\hline
\end{tabular}

\section{DESCRIPTION}

A myriad of ophthalmic disorders are associated with Down's syndrome including refractive errors, strabismus and cataract resulting in significant visual impairment. Haargaard et al estimated a populationbased frequency of $1.4 \%$ of early cataract in Down's syndrome with less than 1\% requiring surgical intervention. ${ }^{1}$ Morphological variants described in Down's syndrome are punctuate cortical opacities sparing the nucleus, zonular, cortical cataract, with total cataract being the most common. ${ }^{1}{ }^{2}$ We describe few rare congenital cataract morphology observed in two patients with Down's syndrome.

A 2-month-old male child presented with unilateral partially absorbed membranous cataract with dense white anterior capsular plaque (ACP) (figure 1A). The thick plaque was well appreciated on ultrasound biomicroscopy (UBM) at a frequency of $35 \mathrm{MHz}$ as a thick hyperechoic linear line on anterior capsule with loss of lens volume (figure 1B). The histopathology examination of the ACP revealed increased subepithelial fibrosis (figure 1C).

A 2-year-old male child presented with total intumescent cataract with dense ACP Oculus dexter (OD) and a fan-shaped cataract involving the visual axis oculus sinister (OS) (figure 2A,C) better appreciated on UBM (figure 2B,D).
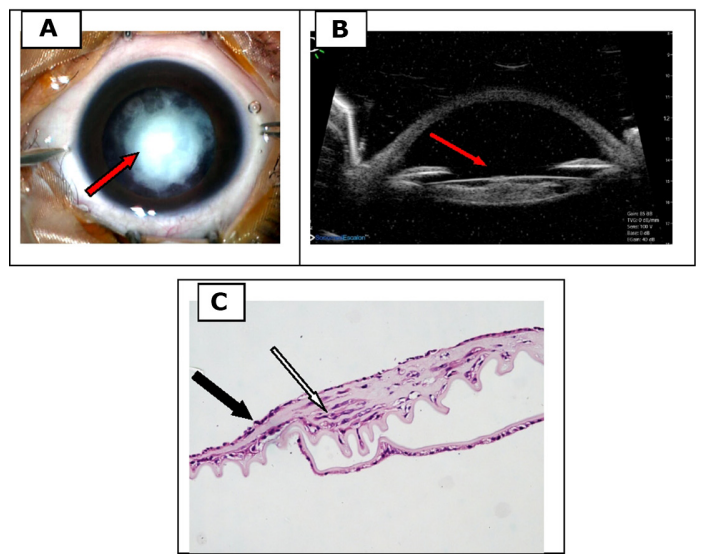

Figure 1 Clinical photograph of membranous cataract in a 2-month-old child with Down's syndrome with thick anterior capsular plaque at the centre (red arrow, A), detected by a dense homogeneous hyperechoic linear line on ultrasound biomicroscopy (red arrow, B). Histopathological examination under H\&E stain of the capsular plaque depicted the anterior cuboidal epithelium cells of the anterior capsule (black arrow, C) with increase in extracellular matrix and fibroblast deposition (white arrow, C).
Plaques are formed when lens epithelial cells (LECs) undergo epithelial mesenchymal transdifferentiation (EMT) into myofibroblasts and secrete extracellular matrix. $^{34}$

It takes place in two phases-proliferative phase where cells undergo rapid proliferation and transdifferentiation phase secreting extracellular matrix. Occurrence of ACP in paediatric patients may be due to the high proliferation capacity of paediatric LECs. ${ }^{5}$ The occurrence of ACP has been found to be more in eyes with mature cataract. ${ }^{5}$

Fan-shaped cataract is a rare finding, reported in a previous paper with an autosomal dominant inheritance in association with microcornea. This characteristic phenotype was linked to the mutation in $\alpha$-crystallin (CRYAA) gene. ${ }^{6}$ The $\alpha$-crystallins comprise up to $40 \%$ of lens protein, acting as molecular chaperones facilitating proper folding of other lens protein and maintaining proper functional state. ${ }^{7} \mathrm{~A}$ fan-shaped nuclear opacification has been reported in another paper with an X-linked inheritance with genetic locus on chromosome Xp22. ${ }^{8}$

There are about 45 genetic loci at present to which isolated cataracts have been mapped with 38 specific genes known in inherited cataracts. ${ }^{9}$ The gene found in this Indian family with fan-shaped cataract has a
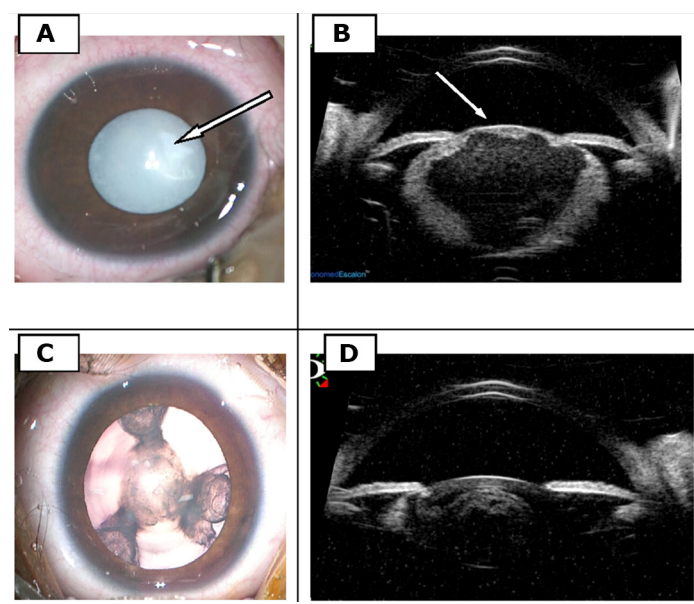

Figure 2 Clinical photograph of total intumescent cataract with thick dense anterior capsular plaque (white arrow, A) with homogeneous hyperechoic linear line corroborating to the plaque on ultrasound biomicroscopy (UBM) (white arrow, B). Clinical photograph of a typical fan-shaped cataract with three radial spokes of triangular-shaped nuclear opacification radiating from a central zonular opacification in a 2-year-old child with Down's syndrome (C). UBM depicts the central opacification of the lens (D). 
genetic locus on chromosome 21 and Down's syndrome is caused by trisomy 21, a coincidental observation.

To the best of our knowledge, ACPs and fan-shaped congenital cataracts have not been reported in association with Down's syndrome.

\section{Patient's perspective}

If more awareness was created at the time of birth of my child, I would have brought for routine ophthalmological screening earlier.

\section{Learning points}

- Periodic ophthalmic evaluation is recommended since early childhood in Down's syndrome for early detection of congenial cataract and other ophthalmic disorders.

- Ultrasound biomicroscopy imaging enables better appreciation of the morphological anomalies prior to surgery, hence enabling better surgical planning.

- Anterior capsular plaque (ACP) in paediatric population can occur even without trauma or any other component of ocular inflammation.

- Presence of dense ACP in Down's syndrome depicts the long-standing proliferation and transdifferentiation changes occurring in lens epithelial cells.

Contributors Professor SK has performed the surgeries. Dr MB has drafted the manuscript and worked up the cases. Dr SJSR has drafted the manuscript and done a literature search. Dr SS has retrieved the images.
Funding The authors have not declared a specific grant for this research from any funding agency in the public, commercial or not-for-profit sectors.

Disclaimer Case reports provide a valuable learning resource for the scientific community and can indicate areas of interest for future research. They should not be used in isolation to guide treatment choices or public health policy.

Competing interests None declared.

Patient consent for publication Obtained

Provenance and peer review Not commissioned; externally peer reviewed.

ORCID iD

Mousumi Banerjee http://orcid.org/0000-0003-4346-246X

\section{REFERENCES}

1 Haargaard B, Fledelius HC. Down's syndrome and early cataract. Br J Ophthalmol 2006:90:1024-7.

2 Lim Z, Rubab S, Chan YH, et al. Pediatric cataract: the Toronto experience-etiology. Am J Ophthalmol 2010;149:887-92.

3 Lovicu FJ, Ang S, Chorazyczewska M, et al. Deregulation of lens epithelial cell proliferation and differentiation during the development of TGFbeta-induced anterior subcapsular cataract. Dev Neurosci 2004;26:446-55.

4 Vasavada AR, Thampi P, Bhatt DS. Degeneration and transdifferentiation of human lens epithelial cells. J Cataract Refract Surg 1999:25:1312-3.

5 Johar K, Vasavada AR, Tatsumi K, et al. Anterior capsular plaque in congenital cataract: occurrence, morphology, immunofluorescence, and ultrastructure. Invest Ophthalmol Vis Sci 2007;48:4209-14.

6 Vanita V, Singh JR, Hejtmancik JF, et al. A novel fan-shaped cataract-microcornea syndrome caused by a mutation of CRYAA in an Indian family. Mol Vis 2006;12:518-22.

7 Kumar LV, Ramakrishna T, Rao CM. Structural and functional consequences of the mutation of a conserved arginine residue in alphaA and alphaB crystallins. J Biol Chem 1999:274:24137-41.

8 Francis PJ, Berry V, Hardcastle AJ, et al. A locus for isolated cataract on human XP. J Med Genet 2002:39:105-9.

9 Shiels A, Hejtmancik JF. Genetics of human cataract. Clin Genet 2013;84:120-7

Copyright 2021 BMJ Publishing Group. All rights reserved. For permission to reuse any of this content visit

https://www.bmj.com/company/products-services/rights-and-licensing/permissions/

BMJ Case Report Fellows may re-use this article for personal use and teaching without any further permission.

Become a Fellow of BMJ Case Reports today and you can:

- Submit as many cases as you like

Enjoy fast sympathetic peer review and rapid publication of accepted articles

- Access all the published articles

Re-use any of the published material for personal use and teaching without further permission

Customer Service

If you have any further queries about your subscription, please contact our customer services team on +44 (0) 2071111105 or via email at support@bmj.com.

Visit casereports.bmj.com for more articles like this and to become a Fellow 